\title{
Fenomenografia ja variaatioteoria aikuiskasvatustieteen tutkimuksessa
}

LAADULLISTEN MENETELMIEN KIRJO on aikuiskasvatustieteellisessä tutkimuksessa lisääntynyt merkittävästi viimeisen kahdenkymmenen vuoden aikana. Lisäksi laadullisia menetelmiä voidaan soveltaa tutkimuksessa usealla eri tavalla, kunhan valintansa osaa perustella kestävästi. Tällaisessa moniparadigmaattisessa tilanteessa (Heikkinen, Huttunen, Niglas \& Tynjälä 2005) erilaiset tutkimussuuntaukset hakevat omaa paikkaansa ja oikeuttavat olemassaoloaan erottautumalla muista. Niin tekee myös fenomenografia, joka alun perin syntyi enemmänkin empiirisenä kuin tieteenfilosofisena tutkimussuuntauksena (Åkerlind 2012).

Alkuvuosinaan 1980-luvulla suuntaus pyrki sanoutumaan irti naiivista realismista ja positivistisesta tieteenfilosofiasta ottamalla käyttöön käsiteparin ensimmäisen ja toisen asteen näkökulmat. 1990-luvulla vahvistui näkemys fenomenografiasta erityisesti käsitysten tutkimuksena. Lähtökohtana oli - ja on edelleen - ajatus siitä, että on olemassa vain rajattu määrä tapoja, joilla ihmiset kokevat, käsittävät ja ymmärtävät tiettyä ilmiötä (Marton 1994). Vielä nykyäänkin käsitysten erilaisuuden löytäminen ja kuvaaminen sekä käsitysten välisten suhteiden ymmärtäminen mielletään fenomenografisen tutkimuksen tunnuspiirteenä ja tavoitteena.

Viime vuosina fenomenografian pohjalta ja osin sen rinnalle on kehittynyt teoreettisena viitekehyksenä variaatioteoria (Marton \& Trigwell 2000; Marton \& Tsui 2004; Rovio-Johansson \& Ingerman 2016). Tämä on tarkoittanut laajemminkin tieteenfilosofisten ja ontologisten taustasitoumusten määrittelyä fenomenografisen tutkimussuuntauksen parissa.

\section{MENETELMÄN JUURILLA}

Fenomenografian tieteenfilosofiset perusjuuret kumpuavat vahvimmin konstruktivismista ja fenomenologiasta (Heikkinen ym. 2005). Konstruoinnin sijaan fenomenografiassa puhutaan konstituoinnista eli siitä, miten käsitykset muodostuvat tai millaisia ne ovat luonteeltaan. Yhtymäkohdista huolimatta fenomenografisesti suuntautuneet tutkijat tekevät käsitteellisen eron kognitiiviseen psykologiaan ja yleisemmin konstuktivismiin. Variaatioteorian myötä fenomenografisen tutkimuksen painopiste on laajentunut käsitysten kuvaamisen lisäksi sen kuvaamiseen, miten ilmiön ymmärtäminen vaihtelee ja miten tämä vaihtelu rakentuu. Viime vuodet ovatkin olleet vilkasta teoreettista keskustelua empirian sijasta erityisesti fenomenografian ja variaatioteorian välisestä suhteesta (Rovio-Johansson \& Ingerman 2016).

Fenomenografista tutkimusta on tehty erityisesti Pohjoismaissa, mutta myös Isossa-Britanniassa ja Australiassa. Lähestymistapana se on lähes tuntematon pohjoisamerikkalaisessa menetelmäkeskustelussa, mikä näkyy suuntauksen puuttumisena alan keskeisestä kirjallisuudesta.

Marton kollegoineen tutki fenomenografian avulla alun perin opiskelijoiden oppimiskäsityksiä ja rakensi tältä pohjalta myöhemmin teoreettista mallia oppimisesta. Myös aikuiskasvatustieteen kentällä tutkimuskohteena ovat olleet erityisesti aikuisten oppimista, ohjaamista, pedagogiikkaa tai kehittämistoimia koskevat käsitykset. Suomessa fenomenografiaa aikuiskasvatustieteessä käyttivät ensimmäisinä Järvinen (1985), Engeström (1990) ja Gröhn (1991). 
Kasvatus- ja opetusalalla työskentelevien tai opiskelevien käsityksiin ovat perehtyneet muun muassa Tynjälä $(1997,1998)$ ja Niikko (2002). Collin (2002) ja Paloniemi (2004) ovat käyttäneet fenomenografiaa työssä tapahtuvaa oppimista tutkiessaan.

Viime vuosina suomalaista fenomenografista tutkimusta on tehty erityisesti korkeakoulututkimuksessa sekä terveys- ja hoitotieteissä. Aikuisopiskelijoiden käsityksiä omasta oppimisestaan tai ohjauksesta tietyissä pedagogisissa käytännöissä (Korhonen 2015) tai koulutusmalleissa (Vehmas 2015) on tutkittu fenomenografisesti. Vastaavasti tutkimus on voinut tarkentua opettajien (Belt 2013; Jokikokko 2015) tai muiden ohjauksen ammattilaisten (Kettunen, Vuorinen \& Sampson 2013) käsitysten tarkasteluun.

Muilla tieteenaloilla fenomenografiaa on käytetty esimerkiksi tutkittaessa digitaalisia peli- ja simulaatioympäristöjä (Whitton 2011) sekä aikuisväestölle suunnattuja ohjaus- ja terveyspalveluja (Laitila 2010) koskevia käyttäjien ja asiakkaiden käsityksiä.

\section{PEDAGOGISEN KEHITTÄMISEN VÄLINE}

Näyttää siltä, että fenomenografiaa hyödyntäneitä aikuisten oppimisen ja ohjaamisen tutkimuksia yhdistää tavoite pedagogisten käytäntöjen kehittämisestä osallistujien käsitysten pohjalta. Tässä mielessä fenomenografinen tutkimus toimii myös systemaattisena käyttäjälähtöisenä arviointitietona ja oppijakeskeisenä pedagogisena kehittämistyön välineenä (Åkerlind 2008). Tällainen kehittävä fenomenografia (Bowden \& Walsh 2005) lähenee aikuiskasvatustieteen kentällä niin kehittävää kuin toimintatutkimuksellistakin lähestymistapaa.

Vaikka fenomenografisen oppimistutkimuksen kritiikki on kohdistunut kapeaan ymmärrykseen oppimisesta pinta- ja syväsuuntautuneena (Haggis 2009), on variaatioteorian ja oppimistutkimuksen näkökulmien yhdistäminen ollut merkittävä sysäys fenomenografiselle oppimistutkimukselle. Siinä missä fenomenografia tarkastelee laadullisesti erilaisia käsittämisen tapoja, tarjoaa variaatioteoria viitekehyksen käsittämisen tapojen erojen ymmärtämiseen. Näitä molempia hyödynnetään edelleen opetuksen kehittämisessä sekä sen tutkimuksessa (Rovio-Johansson \& Ingerman 2016).
Huolimatta siitä, että fenomenografia ei ole erityisen laajasti käytetty aikuiskasvatustieteen kentällä, on sillä kuitenkin jokseenkin vakiintunut asema erityisesti pohjoismaisessa oppimistutkimuksessa. Tästä kertovat niin maaliskuussa 2016 julkaistu fenomenografista kasvatustieteellistä tutkimusta käsittelevä teemanumero (Rovio-Johansson \& Ingerman 2016) kuin asema eurooppalaisessa oppimisen ja opettamisen tutkimuksen verkostossa EARLIssa (European Association of Researching Learning and Instruction), jossa fenomenografialla ja variaatioteorialla on oma aktiivisesti toimiva teemaryhmänsä. Vahvimmin tutkimussuuntaus on esillä alkujuurillaan Göteborgin yliopistossa, missä toimii fenomenografian, variaatioteorian ja oppimistutkimuksen tutkimusryhmä.

Aikuiskasvatustieteelliselle tutkimukselle fenomenografia tarjoaa mahdollisuuden tarkastella erilaisia aikuisten arjen elämänkenttien, koulutuksen, oppimisen ja ohjaamisen ilmiöitä yksilöiden ja yhteisöjen käsitysten kautta.

Aikuisten oppimistutkimuksessa yhtenä keskeisenä tulevaisuuden kehityssuuntana käytännön pedagogisen kehittämisen ohella on näkymä fenomenografisen ja variaatioteoreettisen tutkimuksen käytöstä yhdessä esimerkiksi yhteisöjen diskursiivisten käytäntöjen tai yksilöllisten narratiivien kanssa.

Teoreettisesti ja metodologisesti kiinnostavaa on nähdä, miten fenomenografia ja variaatioteoria tulevaisuudessa pyrkivät erottautumaan ja toisaalta rakentamaan yhtymäkohtia läheisiin tutkimussuuntauksiin (Svensson 2016).

Fenomenografinen luonne määrittyy lopulta siitä, miten käsitysten asema ja merkitys tutkimuksen kokonaisuudessa ymmärretään ja miten niitä lähestytään. Variaatioteoreettinen painotus mahdollistaa tutkimuskohteen laajenemisen erilaisten käsitysten rakentumisen ymmärtämisen tapoihin. Tällöin on mahdollista kysyä, miksi käsittämisen tavat ovat sellaisia kuin ovat ja miten nämä tavat ovat ymmärrettävissä.
Susanna Paloniemi

KT

Jyväskylän yliopisto
Mira Huusko

KT

Helsingin yliopisto 
Belt, A. (2013). Kun työrauha horjuu. Kotitalousopettajien käsityksiä työrauhahäiriöistä ja niiden taustatekijöistä. Oulun yliopisto, Kasvatustieteiden tiedekunta. Acta Univ. Oul. E 135.

Bowden, J. \& Walsh, E. (toim.) (2005). Doing developmental phenomenography. Melbourne: RMIT University Press.

Collin, K. (2002). Development engineers' conceptions of learning at work. Studies in Continuing Education 24(2), 133-152.

Engeström, Y. (1990). Terveyskeskuslääkäreiden työn kehittämistutkimus. LEVIKE-projektin tutkimushankkeen II väliraportti. Espoo: Espoon kaupungin terveysvirasto.

Gröhn, T. (1991). Kotitalouden tieteenalaan liittyvien käsitysten muuttuminen korkeakoulutuksen eri vaiheissa. Helsingin yliopiston opettajankoulutuslaitos. Tutkimuksia 92. Helsinki:Yliopistopaino.

Haggis, T. (2009). What have we been thinking of? A critical overview of 40 years of student learning research in higher education. Studies in Higher Education 34(4), 377-390.

Heikkinen, H. L. T., Huttunen, R., Niglas, K. \& Tynjälä, P. (2005). Kartta kasvatustieteen maastosta. Kasvatus 36(5), 340-354.

Jokikokko, K. (2010). Teachers' intercultural learning and competence. University of Oulu, Faculty of Education, Acta Univ. Oul. E 114.

Järvinen, A. (1985). Lääketieteen opiskelijoiden tieteellisiä ja ammatillisia käsityksiä koskeva seurantatutkimus. Acta Universitatis Tamperensis A 197.

Kettunen, J., Vuorinen, R. \& Sampson, J. P. Jr. (2013). Career practitioners' conceptions of social media in career services. British Journal of Guidance \& Counselling 41(3), 302-317.

Korhonen, H-M. (2015). Mingling in Paedeia Café: student teachers' experiences of participating in peer-mentoring groups of pre-service and in-service teachers. Master's Thesis in Education Faculty of Education. University of Jyväskylä.

Laitila, M. (2010). Asiakkaan osallisuus mielenterveys- ja päihdetyössä. Fenomenografinen lähestymistapa. Publications of the University of Eastern Finland. Dissertations in Health Sciences 31.
Marton, F. (1994). Phenomenography. Teoksessa T. Husén \& T. Neville (toim.) The international encyclopedia of education. 2nd edition, Vol. 8. London: Pergamon, 4424-4429.

Marton, F. \& Trigwell, K. (2000). Variatio est mater studiorum. Higher Education Research and Development 19(3), 381-395.

Marton, F. \& Tsui, A. (2004). Classroom discourse and the space of learning. Hillsdale, NJ: Lawrence Erlbaum.

Niikko, A. (2002). Lastentarhanopettajat esiopetuksen toteuttajina. Kasvatus 33(2), 160-174.

Paloniemi, S. (2004). Ikä, kokemus ja osaaminen työelämässä. Työntekijöiden käsityksiä iän ja kokemuksen merkityksestä ammatillisessa osaamisessa ja sen kehittämisessä. Jyväskylä studies in education, psychology and social research 253.

Rovio-Johansson, A. \& Ingerman, Å. (2016). Continuity and development in the phenomenography and variation theory tradition. Scandinavian Journal of Educational Research 60(3), 257-271.

Svensson, L. (2016). Towards an integration of research on teaching and learning. Scandinavian Journal of Educational Research 60(3), 272-285.

Tynjälä, P. (1997). Developing education students' conceptions of the learning process in different learning environments. Learning and Instruction 7(3), 277-292.

Tynjälä, P. (1998). Writing as a tool for constructive learning: Students' learning experiences during an experiment. Higher Education 36(2), 209-230.

Vehmas, H. (2015). Arvottomuudesta osallisuuteen. Opiskelijoiden käsitykset ohjaavan koulutuksen laadusta työllistymiseen tähtäävien palvelumallien kehittämisen pohjana. Acta Universitatis Tamperensis 2074. Tampere: Tampere University Press.

Whitton, N. (2011). Game engagement theory and adult learning. Simulation \& Gaming 42(5), 596-609.

Åkerlind, G. S. (2008). A phenomenographic approach to developing academics' understanding of the nature of teaching and learning. Teaching in Higher Education 13(6), 633-644.

Åkerlind, G. S. (2012). Variation and commonality in phenomenographic research methods. Higher Education Research \& Development 31(1), 115-137. 